\title{
Idiomarina seosinensis sp. nov., isolated from hypersaline water of a solar saltern in Korea
}

Correspondence

Byung Cheol Cho

bccho@plaza.snu.ac.kr

\author{
Dong Han Choi and Byung Cheol Cho
}

Research Institute of Oceanography and School of Earth and Environmental Sciences, Seoul National University, 56-1 Shillim-dong, Kwanak-gu, Seoul 151-742, Republic of Korea
A halophilic $\gamma$-proteobacterium, designated CL-SP19 ${ }^{\top}$, was isolated from hypersaline water from a solar saltern located in Seosin, Korea. Analysis of the 16S rRNA gene sequence revealed an affiliation with the genus Idiomarina. The sequence similarities between CL-SP19 ${ }^{\top}$ and type strains of the genus Idiomarina ranged from 95.9 to $96.9 \%$. Cells were straight or slightly curved rods and were motile by means of a single polar flagellum. The major fatty acids were $\mathrm{C}_{15: 0}$ iso $(17 \cdot 1 \%)$ and $\mathrm{C}_{17: 0}$ iso $(15 \cdot 2 \%)$. Three fatty acids, $\mathrm{C}_{19: 0} \omega 8 \mathrm{c}$ cyclo $(3.5 \%), \mathrm{C}_{14: 1} \omega 5 \mathrm{c}$ $(1 \cdot 4 \%)$ and $\mathrm{C}_{18: 3} \omega 6 c(1 \cdot 2 \%)$, were found in minor quantities, but uniquely in CL-SP19 ${ }^{\top}$ among Idiomarina species. The DNA G $+\mathrm{C}$ content was $45.0 \mathrm{~mol} \%$. On the basis of its physiology, fatty acid composition and 16S rRNA gene sequence, strain CL-SP $19^{\top}$ could be assigned to the genus Idiomarina but distinguished from the recognized species of the genus. Strain CL-SP19 ${ }^{\top}$, therefore, represents a novel species, for which the name Idiomarina seosinensis sp. nov. is proposed, with CL-SP $19^{\top}\left(=\mathrm{KCTC} 12296^{\top}=\mathrm{JCM} 12526^{\top}\right)$ as the type strain.
The genus Idiomarina was first described by Ivanova et al. (2000). Six species, Idiomarina abyssalis (type species) and Idiomarina zobellii (Ivanova et al., 2000), Idiomarina baltica (Brettar et al., 2003), Idiomarina loihiensis (Donachie et al., 2003), Idiomarina fontislapidosi and Idiomarina ramblicola (Martínez-Cánovas et al., 2004), have been isolated from sea water, i.e. from deep waters of the north-western Pacific Ocean, from surface water of the central Baltic Sea, from hydrothermal fluids from a submarine volcano in Hawaii and from hypersaline habitats in Spain, respectively.

A hypersaline water sample (318 practical salinity units) from a solar saltern in Seosin, Korea, was spread on a plate containing marine agar 2216 (MA; Difco); the plate was incubated at $30^{\circ} \mathrm{C}$ for 2 weeks. Strain CL-SP19 ${ }^{\mathrm{T}}$, appearing as a slightly yellowish colony, was isolated from the plate and subsequently purified four times on $\mathrm{MA}$ at $30^{\circ} \mathrm{C}$. The strain was maintained both on $\mathrm{MA}$ at $4{ }^{\circ} \mathrm{C}$ and in marine broth (MB; Difco) supplemented with $30 \%(\mathrm{v} / \mathrm{v})$ glycerol at $-80{ }^{\circ} \mathrm{C}$.

The 16S rRNA gene was amplified from a single colony by a PCR with Taq DNA polymerase (Bioneer) and primers 27F and 1492R (Lane, 1991). The PCR product was purified

Published online ahead of print on 17 September 2004 as DOI 10.1099/ijs.0.63365-0.

The GenBank/EMBL/DDBJ accession number for the 16S rRNA gene sequence of strain CL-SP19 ${ }^{\top}$ is AY635468.

Additional phenotypic data are available as supplementary material in IJSEM Online. by using the AccuPrep PCR purification kit (Bioneer) and cloned using the pCR2.1 TOPO TA cloning kit (Invitrogen). Sequencing of the 16S rRNA gene was performed with an Applied Biosystems automatic sequencer (ABI3730XL) at Macrogen (Korea). The sequence of strain CL-SP19 ${ }^{\mathrm{T}}$ was compared with 16S rRNA gene sequences available in GenBank, using a BLAST (Altschul et al., 1990) search. The sequence of strain CL-SP $19^{\mathrm{T}}$ was manually aligned with six species of the genus Idiomarina and type species of genera belonging to the family Alteromonadaceae obtained from the GenBank and Ribosomal Database Project (Cole et al., 2003) databases using known 16 S rRNA secondary structure information. Phylogenetic trees were obtained by using neighbour-joining (Saitou \& Nei, 1987), maximumparsimony (Fitch, 1971) and maximum-likelihood (Felsenstein, 1981) methods. An evolutionary distance matrix for the neighbour-joining method was generated according to the model of Jukes \& Cantor (1969). The robustness of tree topologies was assessed by bootstrap analyses based on 1000 replications for neighbour-joining and maximum-parsimony methods and 100 replications for the maximum-likelihood method. Alignment and phylogenetic analyses were carried out using the PHYDIT program (version 3.2, available at http://plaza.snu.ac.kr/ $\sim$ jchun/phydit/) and PAUP ${ }^{\star}$, version 4.0 (Swofford, 1998). Likelihood parameters were estimated by the hierarchical ratio tests in MODELTEST, version 3.04 (Posada \& Crandall, 1998). The almost-complete $16 \mathrm{~S}$ rRNA gene sequence of strain CL-SP19 ${ }^{\mathrm{T}}$ (1463 bp) was obtained. Sequence similarity indicated that the closest relatives of strain CL-SP19 ${ }^{\mathrm{T}}$ were I. fontislapidosi (96.9\%), I. zobellii (96.8\%), I. abyssalis 


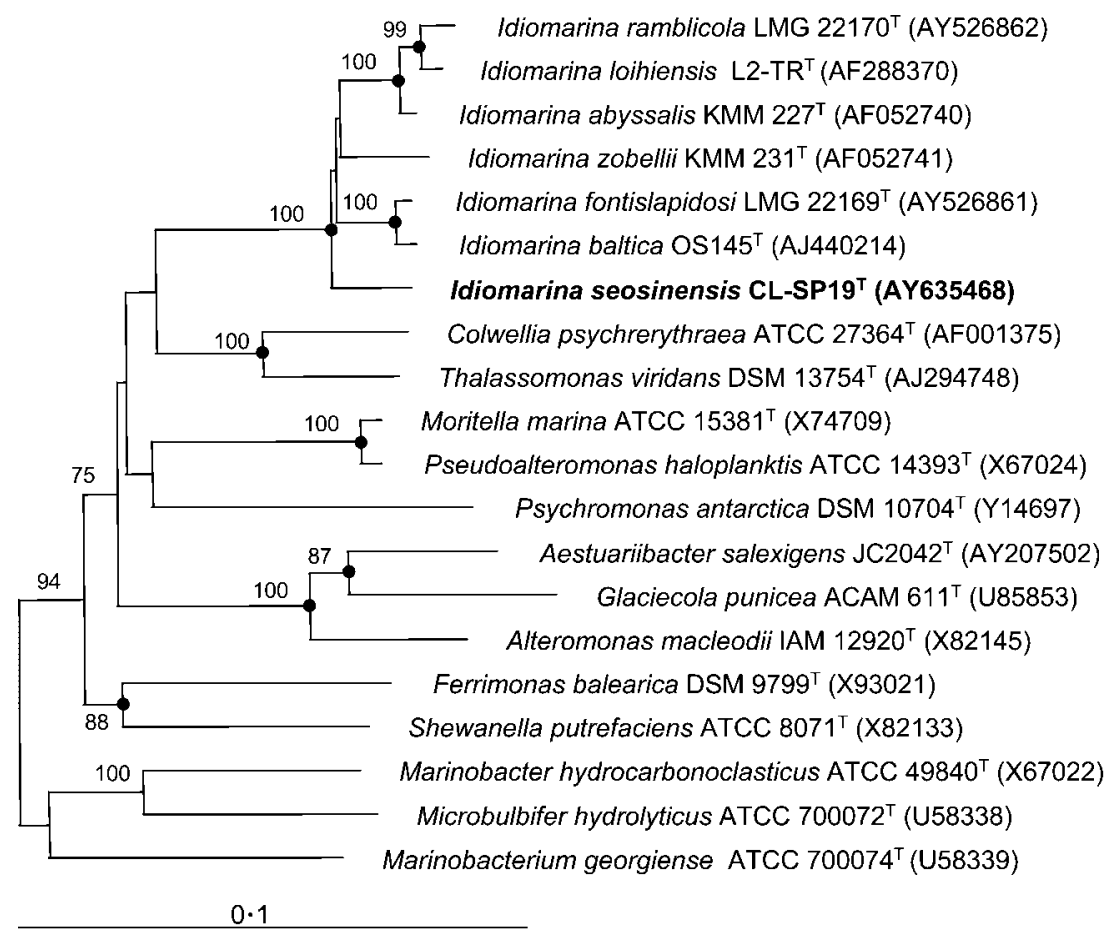

Fig. 1. Neighbour-joining tree showing the relationship between strain CL-SP19 ${ }^{\top}$ and members of Idiomarina and other related genera belonging to the Alteromonadaceae. Only those bootstrap values above $70 \%$ are shown (1000 resamplings) at the branching points. Solid circles indicate that the corresponding nodes are also recovered in maximum-likelihood and maximum-parsimony trees. Burkholderia cepacia (M22518) was used as an outgroup (not shown). Bar, $0 \cdot 1$ nucleotide substitution per site.
(96.8\%), I. baltica $(96 \cdot 4 \%)$, I. loihiensis $(96 \cdot 3 \%)$ and I. ramblicola (95.9\%). Phylogenetic analyses based on the $16 \mathrm{~S}$ rRNA gene sequence showed that strain CL-SP19 ${ }^{\mathrm{T}}$ formed a robust cluster with species of the genus Idiomarina (Fig. 1). Thus, it is clear that our isolate belongs to the genus Idiomarina. However, low similarities (95.9-96.9\%) between the 16S rRNA gene sequence of the novel isolate and those of previously described species of the genus Idiomarina indicated that strain CL-SP19 ${ }^{\mathrm{T}}$ represents a novel species in the genus (Stackebrandt \& Goebel, 1994; Rosselló-Mora \& Amann, 2001).
Subsequently, morphological and physiological tests were also performed. Gram-staining was performed as described by Smibert \& Krieg (1994). Cell morphology and motility were examined by using phase-contrast microscopy (BX60 microscope; Olympus) with cells grown at $30{ }^{\circ} \mathrm{C}$ in $\mathrm{MB}$. The presence of a flagellum was observed using a scanning electron microscope (JSM-6700, FE-SEM; JEOL) (Fig. 2). Anaerobic growth was checked on MA using the GasPak anaerobic system (BBL). Catalase and oxidase activities were determined according to the protocols described by Smibert \& Krieg (1994), while gelatinase, amylase, DNase

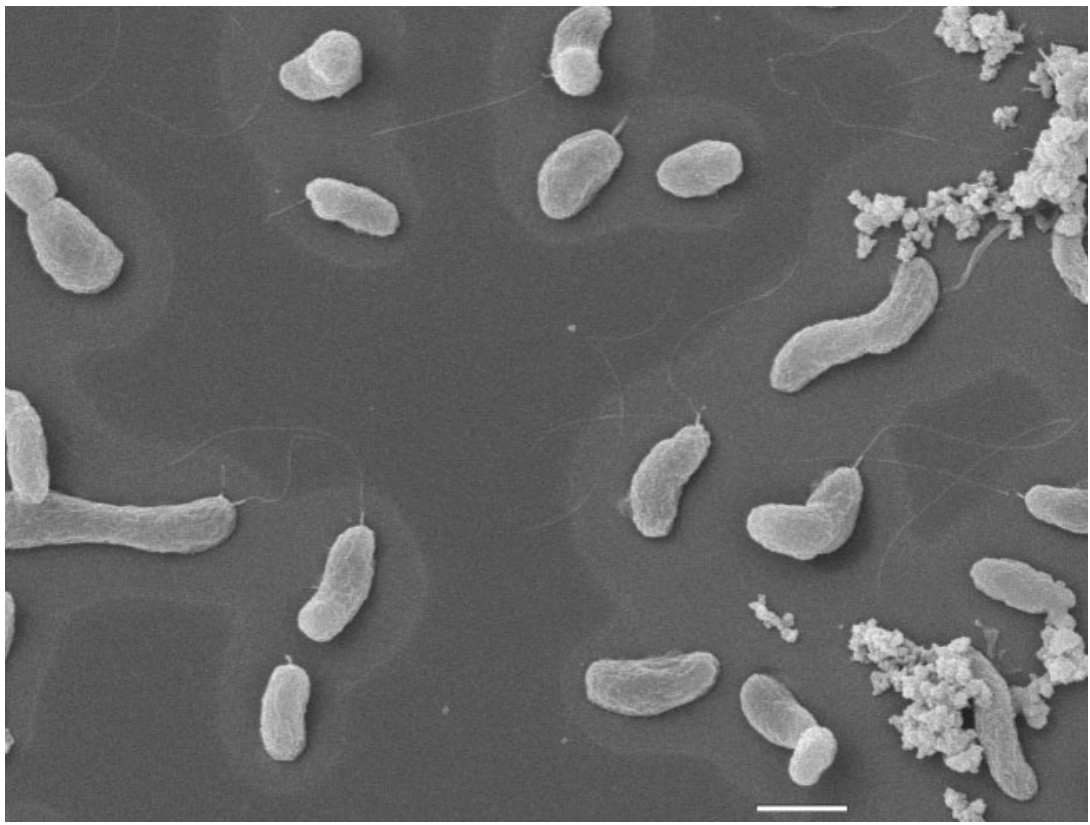

Fig. 2. Scanning electron micrograph of negatively stained cells of strain CL-SP $19^{\top}$. 
and nitrate reductase activities were examined as described by Hansen \& Sørheim (1991).

The temperature range for growth was determined on the basis of colony formation on MA plates that were incubated at $4-46^{\circ} \mathrm{C}$. Optimum temperature (a range of 25 $40^{\circ} \mathrm{C}$ ) and $\mathrm{pH}$ range (a range of $\mathrm{pH} 5-10$ ) for growth were determined by observing changes in $\mathrm{OD}_{600}$ values over time in $\mathrm{MB}$. The final $\mathrm{pH}$ was adjusted using $\mathrm{NaOH}$ and $\mathrm{HCl}$ solutions. The sea salt concentrations allowing growth of CL-SP $19^{T}$ were determined using synthetic ZoBell broth [Bacto peptone (Difco), $5 \mathrm{~g}$; yeast extract, $1 \mathrm{~g}$; ferric citrate, $0 \cdot 1 \mathrm{~g}$; distilled water, 1 litre] with various concentrations of sea salt $(0,0 \cdot 5,1,3,5,7,10,15,20$ and $25 \%, w / v)$. Indole production, acid production from glucose, arginine dihydrolase, urease, hydrolysis of aesculin, and gelatinase and $\beta$-galactosidase were tested using the API 20NE kit (bioMérieux) according to the manufacturer's instructions, except that cell suspensions were prepared using artificial sea water $\left(\mathrm{NaCl}, 24 \mathrm{~g} ; \mathrm{MgCl}_{2}, 5 \cdot 1 \mathrm{~g} ; \mathrm{Na}_{2} \mathrm{SO}_{4}, 4 \mathrm{~g} ; \mathrm{CaCl}_{2}\right.$, $1.1 \mathrm{~g} ; \mathrm{KCl}, 0.7 \mathrm{~g} ; \mathrm{NaHCO}_{3}, 0.2 \mathrm{~g} ; \mathrm{KBr}, 0.1 \mathrm{~g} ; \mathrm{H}_{3} \mathrm{BO}_{3}$, $0.027 \mathrm{~g} ; \mathrm{SrCl}_{2}, 0.024 \mathrm{~g}$; NaF, $0.003 \mathrm{~g}$; distilled water, 1 litre; Yi \& Chun, 2004) as the suspension medium. Other enzyme activities were also assayed, using the API ZYM kit (bioMérieux) and artificial sea water as the suspension medium. The utilization of single carbon sources was investigated using Biolog GN plates and using artificial sea water for cell suspension; the results were read visually after incubation for 1, 2, 3 and 5 days. For the analyses of API 20NE, API ZYM and Biolog, I. loihiensis L2-TR ${ }^{\mathrm{T}}, I$. baltica OS145 ${ }^{\mathrm{T}}$, I. abyssalis KMM $227^{\mathrm{T}}$ and I. zobellii $\mathrm{KMM}$
$231^{\mathrm{T}}$ were employed as reference strains. The results of morphological, biochemical and physiological tests are given in Table 1 and Table 2 and in the species description. The DNA G $+\mathrm{C}$ content was determined by HPLC analysis (Tamaoka \& Komagata, 1984) at the Korean Culture Centre of Microorganisms. The results are shown in Table 1 and in the species description.

The fatty acid methyl esters in whole cells grown at $30^{\circ} \mathrm{C}$ for 2 days on MA were analysed by GC, according to the instructions of the Microbial Identification System (MIDI), at the Korean Culture Centre of Microorganisms. The profile for strain CL-SP $19^{\mathrm{T}}$ shows a predominance of iso-branched fatty acids, which is characteristic of the genus Idiomarina (Table 3). However, in CL-SP19 ${ }^{\mathrm{T}}$, the proportion of $15: 0$ iso fatty acids $(17 \cdot 1 \%)$ is obviously lower than those of other Idiomarina species $(24 \cdot 7-40 \cdot 6 \%)$, whilst the proportion of $17: 0$ iso fatty acids is slightly higher in strain CL-SP $19^{\mathrm{T}}(15 \cdot 2 \%)$ than in Idiomarina species $(8 \cdot 8-12 \cdot 9 \%)$. Three fatty acids, $\mathrm{C}_{19: 0} \omega 8 \mathrm{c}$ cyclo $(3 \cdot 5 \%), \mathrm{C}_{14: 1} \omega 5 c(1 \cdot 4 \%)$ and $\mathrm{C}_{18: 3} \omega 6 c(1 \cdot 2 \%)$, were found in minor quantities, but uniquely in CL-SP $19^{\mathrm{T}}$ among Idiomarina species. Therefore, the fatty acid pattern of strain CL-SP $19^{\mathrm{T}}$ differs distinctly from those of previously described species of Idiomarina.

Phylogenetic analyses based on 16S rRNA gene sequences, fatty acid profiles and physiological features suggest that strain CL-SP $19^{\mathrm{T}}$ represents a novel species of the genus Idiomarina, for which the name Idiomarina seosinensis sp. nov. is proposed.

Table 1. Selected phenotypic characteristics of Idiomarina seosinensis sp. nov. and other Idiomarina species

Strains: 1, I. seosinensis CL-SP19 ${ }^{\mathrm{T}}$ (this study); 2, I. abyssalis KMM $227^{\mathrm{T}}$ (Ivanova et al., 2000); 3, I. zobellii KMM $231^{\mathrm{T}}$ (Ivanova et al.,

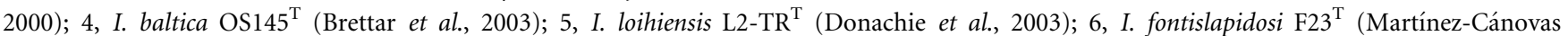
et al., 2004); 7, I. ramblicola $\mathrm{R} 22^{\mathrm{T}}$ (Martínez-Cánovas et al., 2004). ND, No data available; +, positive response; -, negative response. All strains are Gram-negative.

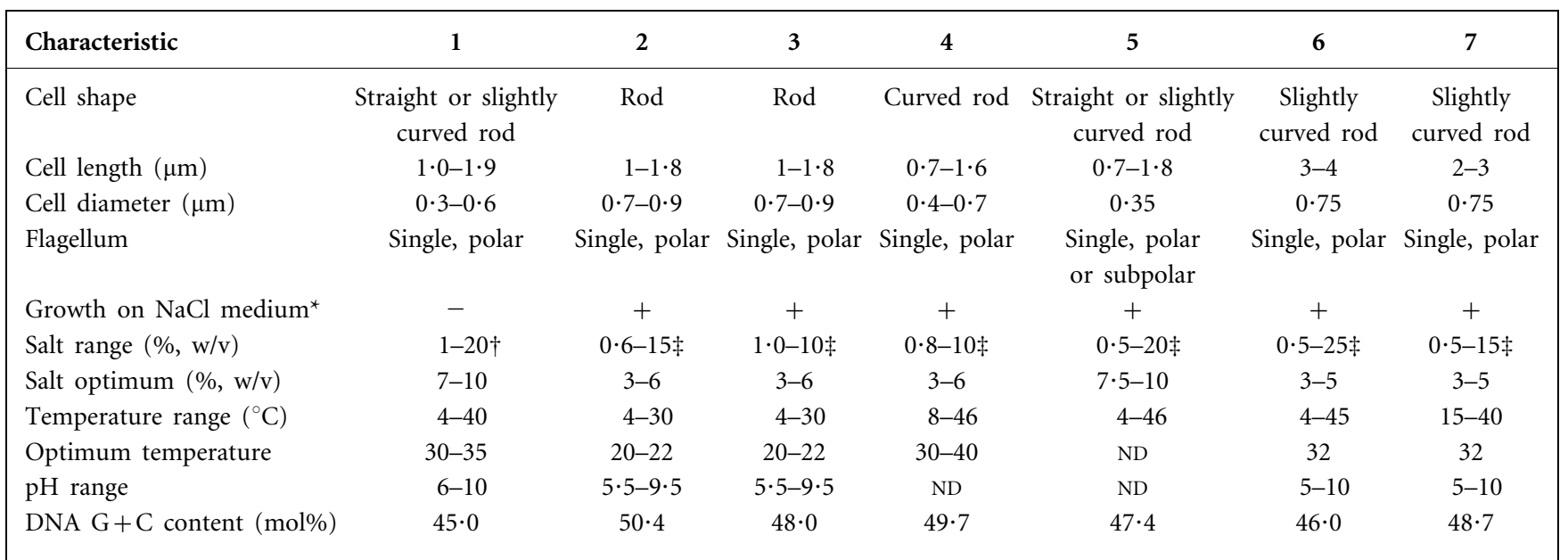

${ }^{\star}$ Medium supplemented with $\mathrm{NaCl}$ as sole salt.

$\dagger$ Sea salt concentration.

$\ddagger \mathrm{NaCl}$ concentration. 
Table 2. Selected phenotypic characteristics that differentiate Idiomarina seosinensis sp. nov. from other Idiomarina species

Strains: 1, I. seosinensis CL-SP19 ${ }^{\mathrm{T}}$; 2, I. abyssalis KMM $227^{\mathrm{T}}$; 3, I. zobellii KMM $231^{\mathrm{T}} ; 4$, I. baltica $\mathrm{OS}_{145^{\mathrm{T}}} ; 5$, I. loihiensis $\mathrm{L}_{2}-\mathrm{TR}^{\mathrm{T}}$. + , Positive response; -, negative response; $\mathrm{W}$, weak response. Data for all strains in the table were obtained in this study. Additional phenotypic data are available as supplementary material in IJSEM Online.

\begin{tabular}{|c|c|c|c|c|c|}
\hline Characteristic & 1 & 2 & 3 & 4 & 5 \\
\hline \multicolumn{6}{|l|}{ API 20NE } \\
\hline Nitrate reduction ${ }^{*}$ & + & + & - & - & - \\
\hline Aesculin hydrolysis & + & - & - & + & - \\
\hline Gelatinase $\dagger$ & - & - & - & + & + \\
\hline \multicolumn{6}{|l|}{ API ZYM } \\
\hline Valine arylamidase & - & - & - & + & - \\
\hline Cystine arylamidase & - & - & - & + & $\mathrm{w}$ \\
\hline Trypsin & - & - & - & - & + \\
\hline$\alpha$-Chymotrypsin & - & - & $\mathrm{W}$ & + & $\mathrm{w}$ \\
\hline Naphthol-phosphohydrolase & - & + & $\mathrm{W}$ & + & $\mathrm{w}$ \\
\hline \multicolumn{6}{|l|}{ Biolog } \\
\hline Glycogen & + & - & $\mathrm{W}$ & - & + \\
\hline$\alpha$-D-Glucose & - & - & + & - & + \\
\hline Pyruvic acid methyl ester & - & + & $\mathrm{W}$ & $\mathrm{W}$ & + \\
\hline Succinic acid mono-methyl-ester & $\mathrm{w}$ & - & - & - & - \\
\hline Acetic acid & - & + & - & + & + \\
\hline$\beta$-Hydroxybutyric acid & $\mathrm{W}$ & - & - & $\mathrm{W}$ & $\mathrm{W}$ \\
\hline$\gamma$-Hydroxybutyric acid & - & - & - & - & + \\
\hline Propionic acid & - & + & - & + & $\mathrm{W}$ \\
\hline Succinic acid & + & $\mathrm{W}$ & + & - & $\mathrm{W}$ \\
\hline D-Alanine & + & - & - & - & - \\
\hline L-Asparagine & + & - & + & + & + \\
\hline L-Aspartic acid & + & - & + & - & - \\
\hline L-Glutamic acid & + & - & + & + & + \\
\hline Glycyl-L-aspartic acid & - & - & + & + & + \\
\hline L-Leucine & - & - & $\mathrm{W}$ & - & + \\
\hline L-Proline & + & - & - & + & + \\
\hline L-Serine & - & + & + & + & + \\
\hline L-Threonine & + & - & + & + & + \\
\hline
\end{tabular}

${ }^{*}$ Test was also performed by Hansen \& Sørheim (1991) and gave congruent results.

$\dagger$ Test was also performed by Hansen \& Sørheim (1991) and showed positive response in all strains tested.

\section{Description of Idiomarina seosinensis sp. nov.}

Idiomarina seosinensis (se.o.sin.en'sis. N.L. fem. adj. seosinensis referring to the Seosin region in Korea, where the type strain was found).

Cells are Gram-negative, strictly aerobic and straight or slightly curved rods that are approximately $0 \cdot 3-0 \cdot 6 \mu \mathrm{m}$ wide and $1 \cdot 0-1 \cdot 9 \mu \mathrm{m}$ long. Motile by means of a single polar flagellum. On MA solid medium, colonies are slightly yellowish, entire circular, convex, opaque and shiny. After
Table 3. Fatty acid compositions of Idiomarina seosinensis sp. nov. and other Idiomarina species

Strains: 1, I. seosinensis CL-SP19 ${ }^{\mathrm{T}}$ (this study); 2, I. abyssalis KMM $227^{\mathrm{T}}$ (Ivanova et al., 2000); 3, I. zobellii KMM $231^{\mathrm{T}}$ (Ivanova et al., 2000); 4, I. baltica OS145 ${ }^{\mathrm{T}}$ (Brettar et al., 2003);

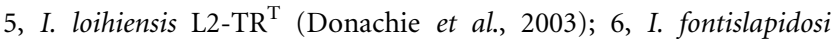
F23 ${ }^{\mathrm{T}}$ (Martínez-Cánovas et al., 2004); 7, I. ramblicola $\mathrm{R} 22^{\mathrm{T}}$ (Martínez-Cánovas et al., 2004). -, Not detected or $<1 \%$.

\begin{tabular}{|c|c|c|c|c|c|c|c|}
\hline Fatty acid & 1 & 2 & 3 & 4 & 5 & 6 & 7 \\
\hline $\mathrm{C}_{14: 0}$ & $0 \cdot 5$ & - & - & - & $0 \cdot 8$ & $1 \cdot 9$ & $0 \cdot 6$ \\
\hline $\mathrm{C}_{16: 0}$ & $8 \cdot 9$ & $6 \cdot 3$ & $4 \cdot 6$ & $4 \cdot 8$ & $7 \cdot 6$ & $11 \cdot 7$ & $7 \cdot 4$ \\
\hline $\mathrm{C}_{17: 0}$ & $0 \cdot 8$ & - & - & - & $0 \cdot 8$ & $0 \cdot 6$ & $1 \cdot 7$ \\
\hline $\mathrm{C}_{18: 0}$ & $3 \cdot 9$ & $1 \cdot 8$ & $0 \cdot 8$ & $0 \cdot 9$ & $1 \cdot 6$ & $4 \cdot 9$ & $3 \cdot 0$ \\
\hline $\mathrm{C}_{11: 0}$ iso & $3 \cdot 2$ & - & - & $2 \cdot 5$ & $2 \cdot 0$ & $2 \cdot 8$ & $3 \cdot 4$ \\
\hline $\mathrm{C}_{13: 0}$ iso & - & $1 \cdot 0$ & $1 \cdot 1$ & $0 \cdot 8$ & $1 \cdot 8$ & $0 \cdot 9$ & $1 \cdot 5$ \\
\hline $\mathrm{C}_{15: 0}$ iso & $17 \cdot 1$ & $33 \cdot 7$ & $40 \cdot 6$ & $36 \cdot 9$ & $32 \cdot 6$ & $26 \cdot 8$ & $24 \cdot 7$ \\
\hline $\mathrm{C}_{15: 1}$ isoF & $0 \cdot 6$ & $2 \cdot 3$ & $1 \cdot 6$ & $1 \cdot 5$ & $1 \cdot 3$ & $1 \cdot 5$ & $1 \cdot 9$ \\
\hline $\mathrm{C}_{17: 0}$ iso & $15 \cdot 2$ & $11 \cdot 9$ & $12 \cdot 5$ & $11 \cdot 2$ & $11 \cdot 0$ & $8 \cdot 8$ & $12 \cdot 9$ \\
\hline $\mathrm{C}_{15: 0}$ anteiso & - & - & - & - & $0 \cdot 3$ & $0 \cdot 6$ & $1 \cdot 2$ \\
\hline $\mathrm{C}_{14: 1} \omega 5 c$ & $1 \cdot 4$ & - & - & - & - & - & - \\
\hline $\mathrm{C}_{15: 1} \omega 8 c$ & - & $1 \cdot 3$ & $1 \cdot 1$ & - & - & - & - \\
\hline $\mathrm{C}_{16: 1} \omega 7 c$ & $2 \cdot 5^{\star}$ & $7 \cdot 0$ & $8 \cdot 3$ & $8 \cdot 4$ & $6 \cdot 0$ & $11 \cdot 3^{\star}$ & $5 \cdot 2$ \\
\hline $\mathrm{C}_{17: 1} \omega 6 c$ & - & $1 \cdot 5$ & $3 \cdot 4$ & - & - & - & - \\
\hline $\mathrm{C}_{17: 1} \omega 8 c$ & - & $0 \cdot 8$ & $1 \cdot 1$ & $0 \cdot 7$ & $0 \cdot 9$ & $0 \cdot 3$ & $1 \cdot 1$ \\
\hline $\mathrm{C}_{17: 1} \omega 9 c$ iso & $8 \cdot 8$ & - & - & $10 \cdot 0$ & $11 \cdot 9$ & $4 \cdot 0$ & $11 \cdot 0$ \\
\hline $\mathrm{C}_{18: 1} \omega 7 c$ & $8 \cdot 7$ & $6 \cdot 7$ & $5 \cdot 9$ & $6 \cdot 0$ & $5 \cdot 5$ & $9 \cdot 3$ & $5 \cdot 9$ \\
\hline $\mathrm{C}_{18: 1} \omega 7 c$ 11-methyl & - & - & - & $1 \cdot 8$ & - & $0 \cdot 9$ & $0 \cdot 2$ \\
\hline $\mathrm{C}_{18: 1} \omega 9 c$ & $0 \cdot 8$ & $1 \cdot 4$ & $0 \cdot 9$ & $0 \cdot 9$ & $1 \cdot 0$ & $1 \cdot 1$ & $1 \cdot 2$ \\
\hline $\mathrm{C}_{18: 3} \omega 6 c(6,9,12)$ & $1 \cdot 2$ & - & - & - & - & - & - \\
\hline $\mathrm{C}_{19: 1} \omega 6 c$ & $2 \cdot 1$ & - & - & $0 \cdot 4$ & $0 \cdot 6$ & - & - \\
\hline $\mathrm{C}_{10: 0} 3-\mathrm{OH}$ & $1 \cdot 3$ & - & - & $1 \cdot 2$ & $0 \cdot 8$ & $2 \cdot 3$ & $1 \cdot 1$ \\
\hline $\mathrm{C}_{12: 0} 3-\mathrm{OH}$ & $1 \cdot 2$ & - & - & - & $0 \cdot 7$ & - & - \\
\hline $\mathrm{C}_{11: 0}$ iso $3-\mathrm{OH}$ & $5 \cdot 0$ & - & - & $3 \cdot 7$ & $4 \cdot 1$ & $2 \cdot 6$ & $5 \cdot 6$ \\
\hline $\mathrm{C}_{13: 0}$ iso $3-\mathrm{OH}$ & $4 \cdot 2$ & - & - & $3 \cdot 2$ & $3 \cdot 3$ & $1 \cdot 6$ & $2 \cdot 3$ \\
\hline $\mathrm{C}_{15: 0}$ iso $3-\mathrm{OH}$ & $1 \cdot 2$ & - & - & - & $0 \cdot 5$ & - & - \\
\hline $\mathrm{C}_{17: 0}$ cyclo & $4 \cdot 5$ & - & - & $0 \cdot 6$ & $1 \cdot 7$ & $1 \cdot 2$ & $2 \cdot 5$ \\
\hline $\mathrm{C}_{19: 0} \omega 8 c$ cyclo & $3 \cdot 5$ & - & - & - & - & - & - \\
\hline
\end{tabular}

${ }^{*} \mathrm{C}_{16: 1} \omega 7 c / \mathrm{C}_{15: 0}$ iso $2-\mathrm{OH}$.

3 days on $\mathrm{MA}$ at $30^{\circ} \mathrm{C}$, colonies are approximately $2-3 \mathrm{~mm}$ in diameter. They grow within the temperature range $4-40{ }^{\circ} \mathrm{C}$ (optimum of $30-35^{\circ} \mathrm{C}$ ) and at $\mathrm{pH}$ values between 6 and 10. Growth occurs in sea salt concentrations of 1$20 \%(\mathrm{w} / \mathrm{v})$ (optimum of 5-10\%), whereas no growth occurs in media containing $\mathrm{NaCl}$ as the only salt. Positive for oxidase, catalase, DNase, gelatinase and nitrate reductase activities but negative for amylase activity. The major fatty acids are $15: 0$ iso $(17 \cdot 1 \%)$ and $17: 0$ iso $(15 \cdot 2 \%)$. Minor amounts of $\mathrm{C}_{19: 0} \omega 8 c$ cyclo (3.5\%), $\mathrm{C}_{14: 1} \omega 5 c(1 \cdot 4 \%)$ and $\mathrm{C}_{18: 3} \omega 6 c(1 \cdot 2 \%)$ are also found. In API $20 \mathrm{NE}$ tests, cells are positive for nitrate reductase activity and hydrolysis of aesculin, but negative for indole production, acid production from glucose, arginine dihydrolase, urease, gelatinase and $\beta$-galactosidase. In API ZYM tests, cells are positive for 
alkaline phosphatase, esterase ( $\mathrm{C} 4$ and $\mathrm{C} 8)$ and leucine arylamidase activities, but negative for valine arylamidase, cysteine arylamidase, trypsin, $\alpha$-chymotrypsin and naphthol-phosphohydrolase activities. In Biolog tests, the following substrates are utilized: glycogen, Tween 40 , Tween $80, \alpha$-ketobutyric acid, $\alpha$-ketovaleric acid, succinic acid, L-alaninamide, L-alanine, L-alanylglycine, L-asparagine, L-aspartic acid, L-glutamic acid, glycyl-L-glutamic acid, Lproline and L-threonine. The DNA $\mathrm{G}+\mathrm{C}$ content is $45 \cdot 0 \mathrm{~mol} \%$.

The type strain is CL-SP19 $9^{\mathrm{T}}\left(=\mathrm{KCTC} 12296^{\mathrm{T}}=\mathrm{JCM}\right.$ $12526^{\mathrm{T}}$ ), isolated from hypersaline water from a solar saltern located in Seosin, Korea.

\section{Acknowledgements}

We thank Professor M. Alam for the gift of the type strain of $I$. loihiensis, and Dr J. Chun and Ms H. Lee for discussions and help during this work. This work was supported by the BK21 project of the Korean Government.

\section{References}

Altschul, S. F., Gish, W., Miller, W., Myers, E. W. \& Lipman, D. J. (1990). Basic local alignment search tool. J Mol Biol 215, 403-410.

Brettar, I., Christen, R. \& Höfle, M. G. (2003). Idiomarina baltica sp. nov., a marine bacterium with a high optimum growth temperature isolated from surface water of the central Baltic Sea. Int J Syst Evol Microbiol 53, 407-413.

Cole, J. R., Chai, B., Marsh, T. L. \& 8 other authors (2003). The Ribosomal Database Project (RDP-II): previewing a new autoaligner that allows regular updates and the new prokaryotic taxonomy. Nucleic Acids Res 31, 442-443.

Donachie, S. P., Hou, S., Gregory, T. S., Malahoff, A. \& Alam, M. (2003). Idiomarina loihiensis sp. nov., a halophilic $\gamma$-Proteobacterium from the Lō'ihi submarine volcano, Hawai'i. Int J Syst Evol Microbiol 53, 1873-1879.

Felsenstein, J. (1981). Evolutionary trees from DNA sequences: a maximum likelihood approach. J Mol Evol 17, 368-376.
Fitch, W. M. (1971). Toward defining the course of evolution: minimum change for a specific tree topology. Syst Zool 20, 406-416.

Hansen, G. H. \& Sørheim, R. (1991). Improved method for phenotypical characterization of marine bacteria. J Microbiol Methods 13, 231-241.

Ivanova, E. P., Romanenko, L. A., Chun, J. \& 7 other authors (2000). Idiomarina gen. nov., comprising novel indigenous deep-sea bacteria from the Pacific Ocean, including descriptions of two species, Idiomarina abyssalis sp. nov. and Idiomarina zobellii sp. nov. Int J Syst Evol Microbiol 50, 901-907.

Jukes, T. H. \& Cantor, C. R. (1969). Evolution of protein molecules. In Mammalian Protein Metabolism, pp. 21-132. Edited by H. N. Munro. New York: Academic Press.

Lane, D. J. (1991). 16S/23S rRNA sequencing. In Nucleic Acid Techniques in Bacterial Systematics, pp. 115-175. Edited by E. Stackebrandt \& M. Goodfellow. Chichester: Wiley.

Martínez-Cánovas, M. J., Béjar, V., Martínez-Checa, F., Páez, R. \& Quesada, E. (2004). Idiomarina fontislapidosi sp. nov. and Idiomarina ramblicola sp. nov., isolated from inland hypersaline habitats in Spain. Int J Syst Evol Microbiol 54, 1793-1797.

Posada, D. \& Crandall, K. A. (1998). MODELTEST: testing the model of DNA substitution. Bioinformatics 14, 817-818.

Rosselló-Mora, R. \& Amann, R. (2001). The species concept for prokaryotes. FEMS Microbiol Rev 25, 39-67.

Saitou, N. \& Nei, M. (1987). The neighbor-joining method: a new method for reconstructing phylogenetic trees. Mol Biol Evol 4, $406-425$.

Smibert, R. M. \& Krieg, N. R. (1994). Phenotypic characterization. In Methods for General and Molecular Bacteriology, pp. 607-654. Edited by P. Gerhardt, R. G. E. Murray, W. A. Wood \& N. R. Krieg. Washington, DC: American Society for Microbiology.

Stackebrandt, E. \& Goebel, B. M. (1994). Taxonomic note: a place for DNA-DNA reassociation and 16S rRNA sequence analysis in the present species definition in bacteriology. Int J Syst Bacteriol 44, 846-849.

Swofford, D. L. (1998). PAUP* - Phylogenetic analysis using parsimony, version 4. Sunderland, MA: Sinauer Associates.

Tamaoka, J. \& Komagata, K. (1984). Determination of DNA base composition by reverse-phase high performance liquid chromatography. FEMS Microbiol Lett 25, 125-128.

Yi, H. \& Chun, J. (2004). Nocardioides ganghwensis sp. nov., isolated from tidal flat sediment. Int J Syst Evol Microbiol 54, 1295-1299. 